\title{
A diastereoselective approach to axially chiral biaryls via electrochemically enabled cyclization cascade
}

\author{
Hong Yan ${ }^{1}$, Zhong-Yi Mao ${ }^{1}$, Zhong-Wei Hou ${ }^{1}$, Jinshuai Song ${ }^{2}$ and Hai-Chao Xu ${ }^{* 1}$
}

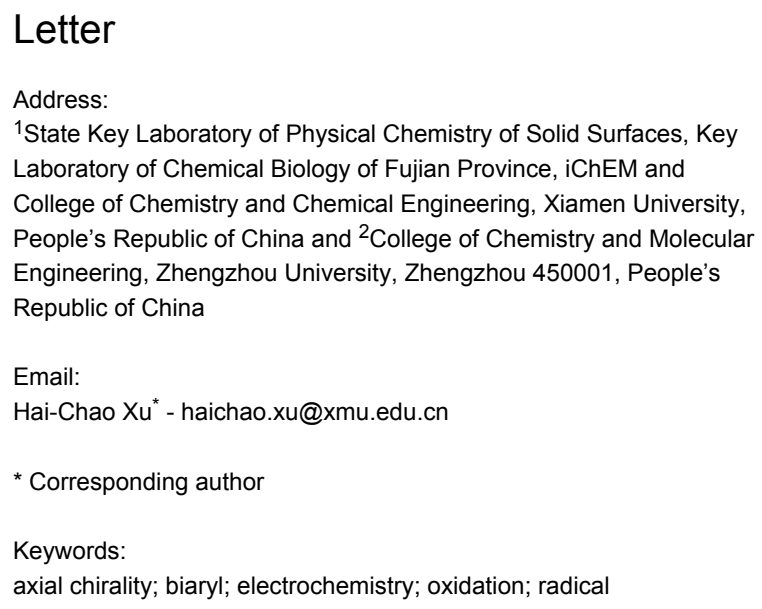

Beilstein J. Org. Chem. 2019, 15, 795-800.

$$
\text { doi:10.3762/bjoc. } 15.76
$$

Received: 03 January 2019

Accepted: 16 March 2019

Published: 28 March 2019

This article is part of the thematic issue "Reactive intermediates part I: radicals".

Guest Editor: T. P. Yoon

(C) 2019 Yan et al.; licensee Beilstein-Institut.

License and terms: see end of document.

\begin{abstract}
\section{Introduction}

Axially chiral biaryls are prevalent in natural products, bioactive molecules and organocatalysts [1,2]. Among the many methods that have been developed for the synthesis of chiral biaryls [3-10], reactions that take avantage of the central-toaxial chirality transfer have been less explored [11-14]. In addition, an antroposelective synthesis of imidazopyridine-based biaryls has not been reported.
\end{abstract}

A diastereoselective approach to axially chiral imidazopyridine-containing biaryls has been developed. The reactions proceed through a radical cyclization cascade to construct the biaryls with good to excellent central-to-axial chirality transfer.

Nitrogen-centered radicals (NCRs) are attractive reactive intermediates for organic synthesis as they provide opportunities for the efficient construction of C-N bonds [15-19]. Recently, the generation of NCRs through electron transfer-based methods has been attracting attention. Organic electrochemistry is a powerful tool for adding or taking electrons from organic mole- cules to promote redox reactions because of its reagent-free feature and the tunability of electric current and potential [20-30]. We [31-34] and others [35-41] have studied the reactions of electrochemically generated NCRs. Particularly, we have recently reported an electrochemical synthesis of imidazo-fused $\mathrm{N}$-heteroaromatic compounds via a radical cyclization cascade [31]. Building on this work, we report herein an atroposelective synthesis of imidazopyridine-containing biaryls via central-toaxial chirality transfer (Scheme 1).

\section{Results and Discussion}

The substituents on the phenyl ring $\left(\mathrm{R}^{1}\right)$ and at the propargylic position $\left(\mathrm{R}^{2}\right)$ of carbamate 2 were varied to study their effects on the diastereoselectivity (Table 1 ). The electrolysis was con- 


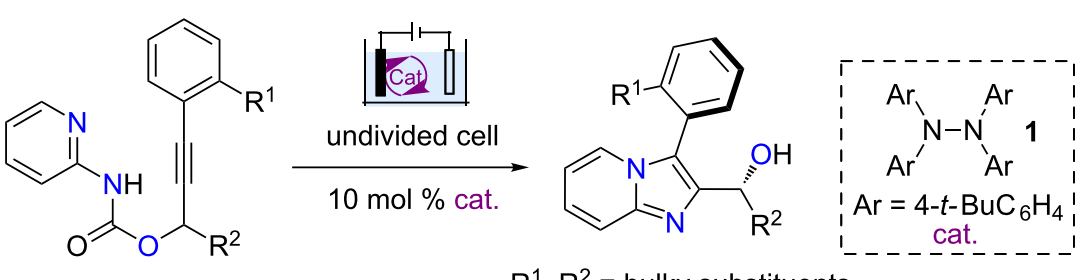

$\mathrm{R}^{1}, \mathrm{R}^{2}=$ bulky substituents

Scheme 1: Reaction design.

Table 1: Investigation on the effects of substituents on the diastereoselectivity. ${ }^{a}$<smiles>[R]c1ccccc1C#CC([R])OC(=O)Nc1ccccn1</smiles>

2a-d

\author{
RVC \\ $1(10 \mathrm{~mol} \%), \mathrm{NaHCO}_{3}$ (2 equiv) \\ $\mathrm{Et}_{4} \mathrm{NBF}_{4}$ (1 equiv), $\mathrm{MeCN} / \mathrm{H}_{2} \mathrm{O}(9: 1)$ \\ reflux, $7.5 \mathrm{~mA}, 3.75 \mathrm{~h}$
}

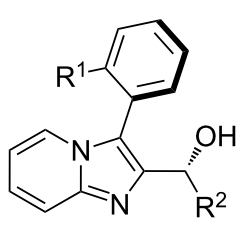

$3 a-d$

\begin{tabular}{lll}
\hline Entry & Substrate & Product, yield, ${ }^{\mathrm{b}} \mathrm{dr} \mathrm{r}^{\mathrm{c}}$ \\
\hline 1 & 2a $\left(\mathrm{R}^{1}=t-\mathrm{Bu}, \mathrm{R}^{2}=t-\mathrm{Bu}\right)$ & $( \pm)-3 \mathbf{a}, 68 \%, 14: 1 \mathrm{dr}$ \\
2 & 2b $\left(\mathrm{R}^{1}=t-\mathrm{Bu}, \mathrm{R}^{2}=\mathrm{iPr}\right)$ & $( \pm)-3 \mathbf{b}, 64 \%, 3: 1 \mathrm{dr}$ \\
3 & 2c $\left(\mathrm{R}^{1}=\mathrm{Ph}, \mathrm{R}^{2}=t-\mathrm{Bu}\right)$ & $( \pm)-3 \mathbf{c}, 73 \%, 2: 1 \mathrm{dr}$ \\
4 & 2d $\left(\mathrm{R}^{1}=\mathrm{OiPr}, \mathrm{R}^{2}=t-\mathrm{Bu}\right)$ & $( \pm)-3 \mathrm{~d}, 78 \%, 3: 1 \mathrm{dr}$ \\
\hline
\end{tabular}

aReaction conditions: undivided cell, 1 (0.03 mmol), $2(0.3 \mathrm{mmol}), \mathrm{H}_{2} \mathrm{O}(1 \mathrm{~mL}), \mathrm{MeCN}(9 \mathrm{~mL}), 3.5 \mathrm{~F} \mathrm{~mol}{ }^{-1}$. ${ }^{b}$ lsolated yield. ${ }^{\mathrm{C}}$ Determined by ${ }^{1} \mathrm{H} \mathrm{NMR}$ analysis of the crude reaction mixture.

ducted under previously established conditions employing a three-necked round-bottomed flask as the cell, a reticulated vitreous carbon (RVC) anode and a platinum plate cathode [31]. The reaction was carried in refluxing $\mathrm{MeCN} / \mathrm{H}_{2} \mathrm{O}$ (9:1) with tetraarylhydrazine 1 as the redox catalyst, $\mathrm{NaHCO}_{3}$ (2 equiv) as an additive, and $\mathrm{Et}_{4} \mathrm{NBF}_{4}$ ( 1 equiv) as the supporting electrolyte. These investigations indicated that bulky tertiary groups at both $\mathrm{R}^{1}$ and $\mathrm{R}^{2}$ positions were needed to ensure efficient chirality transfer. Hence, carbamate $\mathbf{2 a}$ (Table 1, entry 1) bearing a $t$-Bu group at $\mathrm{R}^{1}$ and $\mathrm{R}^{2}$ positions, respectively, reacted to give imidazopyridine-based biaryl $\mathbf{3 a}$ in $68 \%$ yield with good diastereoselectivity (14:1 dr). Replacing the $t$-Bu group at the propargylic position with iPr (Table 1, entry 2 ) or on the phenyl ring with $\mathrm{Ph}$ (Table 1, entry 3 ) or OiPr (Table 1, entry 4) all resulted in low diastereoselectivity (2:1 to $3: 1)$.

The scope of the electrosynthesis was investigated by varying the peripheral substituents of the carbamate substrate 2 (Scheme 2). The pyridyl ring could be substituted at positions 4 , 5 and 6 with a range of substituents with diverse electronic properties such as $\mathrm{OMe}(\mathbf{3 e}), \mathrm{Br}(\mathbf{3 f}), \mathrm{CF}_{3}(\mathbf{3 g}), \mathrm{CN}(\mathbf{3 h}), \mathrm{Cl}$ (3i), and Me (3j). Pyridyl rings bearing multiple substituents were also tolerated (3k and $\mathbf{3 l}$ ). The stereochemistry of the biaryl product was determined by obtaining an X-ray crystal structure of $3 \mathbf{k}$. The $t$-Bu-substituted phenyl ring on the alkyne moiety containing an extra $\mathrm{OMe}(\mathbf{3 m})$ or $\mathrm{Me}(\mathbf{3 n}$ and 3o) group was tolerated albeit with reduced diastereoselectivity. The $t$-Bu group on the phenyl ring and at the propargylic position could be replaced with other bulky tertiary substituents to afford a range of functionalized biaryl products $(\mathbf{3 p}-\mathbf{w})$. The electrochemical conditions were compatible with several functional groups including aryltrimethylsilane (3p), silyl ether $(\mathbf{3 q}-\mathbf{s})$, ester (3t) and cylic ketal (3u). Note that all the diastereomers were separable by flash column chromatography.

Heating a solution of the major isomer of $\mathbf{3 n}$ in $\mathrm{MeCN}$ at $80^{\circ} \mathrm{C}$ for $4 \mathrm{~h}$ did not lead to isomerization, suggesting that the stereoselectivity of the reaction was not controlled by relative thermodynamic stability of the diastereomers. The major isomer of $\mathbf{3 c}$, which contained a sterically less demanding $\mathrm{Ph}$ group at the $\mathrm{R}^{1}$ position (cf. Table 1), did not isomerize at room temperature for 1 year. However, heating a solution of this compound in $\mathrm{MeCN}$ 


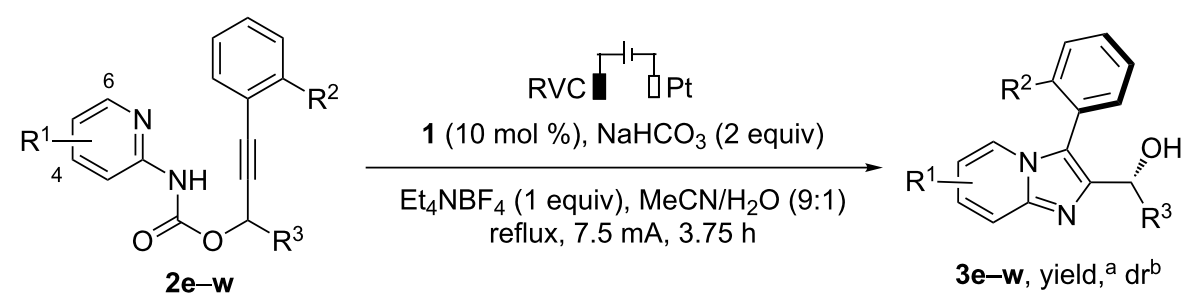<smiles>COc1ccn2c(C(C)(C)C)c(C(O)C(C)(C)C)nc2c1</smiles>

( \pm -3e, $76 \%, 8: 1 d r$<smiles>CC(C)(C)c1ccccc1-c1c(C(O)C(C)(C)C)nc2cccc(Cl)n12</smiles>

$( \pm)-3 \mathbf{i}, 82 \%, 14: 1 \mathrm{dr}$<smiles>Cc1cc2nc(C(O)C(C)(C)C)c(-c3ccccc3C(C)(C)C)n2cc1F</smiles>

$( \pm)-3 \mathbf{l}, 65 \%, 10: 1 \mathrm{dr}$<smiles>CCC(C)(C)[C@H](O)c1nc2ccccn2c1-c1ccccc1S(C)(=O)=O</smiles>

$( \pm)-3 p, 83 \%, 6: 1 d r$<smiles>COC(=O)C(C)(C)c1ccccc1-c1c(C(O)CC(C)(C)C)nc2ccccn12</smiles>

$( \pm)-3 t, 96 \%,>20: 1 d r$<smiles>CC(C)(C)c1ccccc1-c1c(C(O)C(C)(C)C)nc2cc(Br)ccn12</smiles>

( \pm )-3f, $66 \%, 11: 1 d r$<smiles>Cc1cccc2nc([C@H](O)C(C)(C)C)c(-c3ccccc3C(C)(C)C)n12</smiles>

$( \pm)-3 \mathbf{j}, 78 \%, 8: 1 \mathrm{dr}$<smiles>COc1ccc(-c2c(C(O)C(C)(C)C)nc3ccccn23)c(C(C)(C)C)c1</smiles>

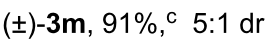<smiles>COC(C)(C)c1ccccc1-c1c([C@H](O)CC(C)(C)C)nc2ccccn12</smiles>

(士)-3q, 88\%, 9:1 dr

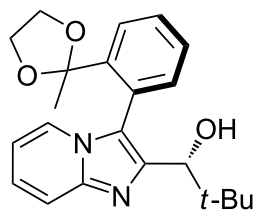

$( \pm)-3 \mathbf{u}, 72 \%, \quad 10: 1 \mathrm{dr}$<smiles>CC(C)(C)c1ccccc1-c1c(C(O)C(C)(C)C)nc2cc(C(F)(F)F)ccn12</smiles>

$( \pm)-3 g, 80 \%, 11: 1 \mathrm{dr}$<smiles>CC(C)(C)c1ccccc1-c1c([C@@H](O)C(C)(C)C)nc2cc(Cl)cc(Cl)n12</smiles>

( \pm )-3k, $48 \%,>20: 1 \mathrm{dr}$<smiles>Cc1ccc(-c2c(C(O)C(C)(C)C)nc3ccccn23)c(C(C)(C)C)c1</smiles>

$( \pm)-3 n, 82 \%,{ }^{c} 7: 1 \mathrm{dr}$<smiles>CCC(C)C(O)c1nc2ccccn2c1-c1ccccc1C(O[Na])(c1ccccc1)C(C)(C)C</smiles>

$( \pm)-3 r, 43 \%,>20: 1 d r$<smiles>CC(C)(C)c1ccccc1-c1c([C@H](O)C(C)(C)Cc2ccccc2)nc2ccccn12</smiles>

$( \pm)-3 v, 70 \%, 9: 1 d r$<smiles>CC(C)(C)c1ccccc1-c1c([C@H](O)C(C)(C)C)nc2ccc(C#N)cn12</smiles>

( \pm )-3h, $62 \%, 12: 1 \mathrm{dr}$

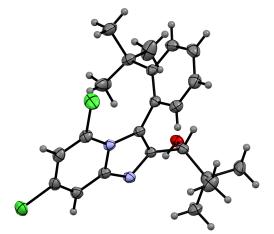

X-ray (3k) [CCDC 1888229]

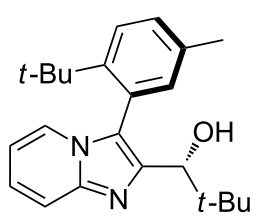

(士)-3o, 75\%, 10:1 dr

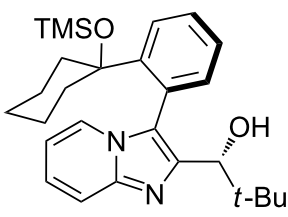

( \pm -3s, $55 \%, 10: 1 \mathrm{dr}$

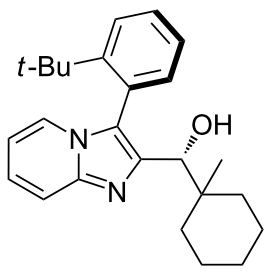

$( \pm)-3 w, 64 \%, 8: 1 d r$

Scheme 2: Scope of electrochemical synthesis of axially chiral biaryls. Reaction conditions: undivided cell, $2(0.3 \mathrm{mmol}), \mathrm{H}_{2} \mathrm{O}(1 \mathrm{~mL}), \mathrm{MeCN}(9 \mathrm{~mL})$,

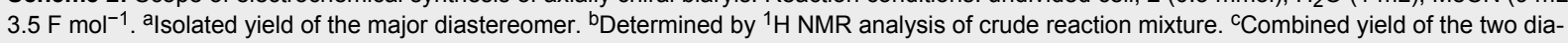
stereomers. 
at $80^{\circ} \mathrm{C}$ for $4 \mathrm{~h}$ resulted in a mixture of diastereomers in a ratio of $3: 1$. These results suggest that the sterically demanding substituents at $\mathrm{R}^{1}$ and $\mathrm{R}^{2}$ positions (cf. Table 1) are critical to ensure good stereoselectivity during the product formation and to prevent isomerization after the reaction.

A mechanism for the electrochemical synthesis was proposed based on the results from our previous work [31] and of this work (Scheme 3 ). The redox catalyst $\mathbf{1}$ is oxidized at the anode to give radical cation $\mathbf{I}$. In the meanwhile, $\mathrm{H}_{2} \mathrm{O}$ is reduced at the cathode to afford $\mathrm{HO}^{-}$and $\mathrm{H}_{2}$. The base generated at the cathode deprotonates $\mathbf{2 a}$ to give its conjugate base II. The an- ionic II is oxidized by radical cation I through single electron transfer (SET) to give radical intermediate III, which undergoes a biscyclization to give $\mathbf{V}$. Further oxidation of $\mathbf{V}$ followed by hydrolysis of the cyclic carbamate moiety leads to the formation of $\mathbf{3 a}$.

Based on the proposed reaction mechanism and the results mentioned above, the cyclization of vinyl radical IV to give $\mathbf{V}$ is the atroposelective step. Density functional theory (DFT)based calculations suggested that the cyclization of $\mathbf{I V}$ could be explained by a Curtin-Hammett scenario (Scheme 4) [42]. Specifically, the equilibrium of the conformations IV and IV' is

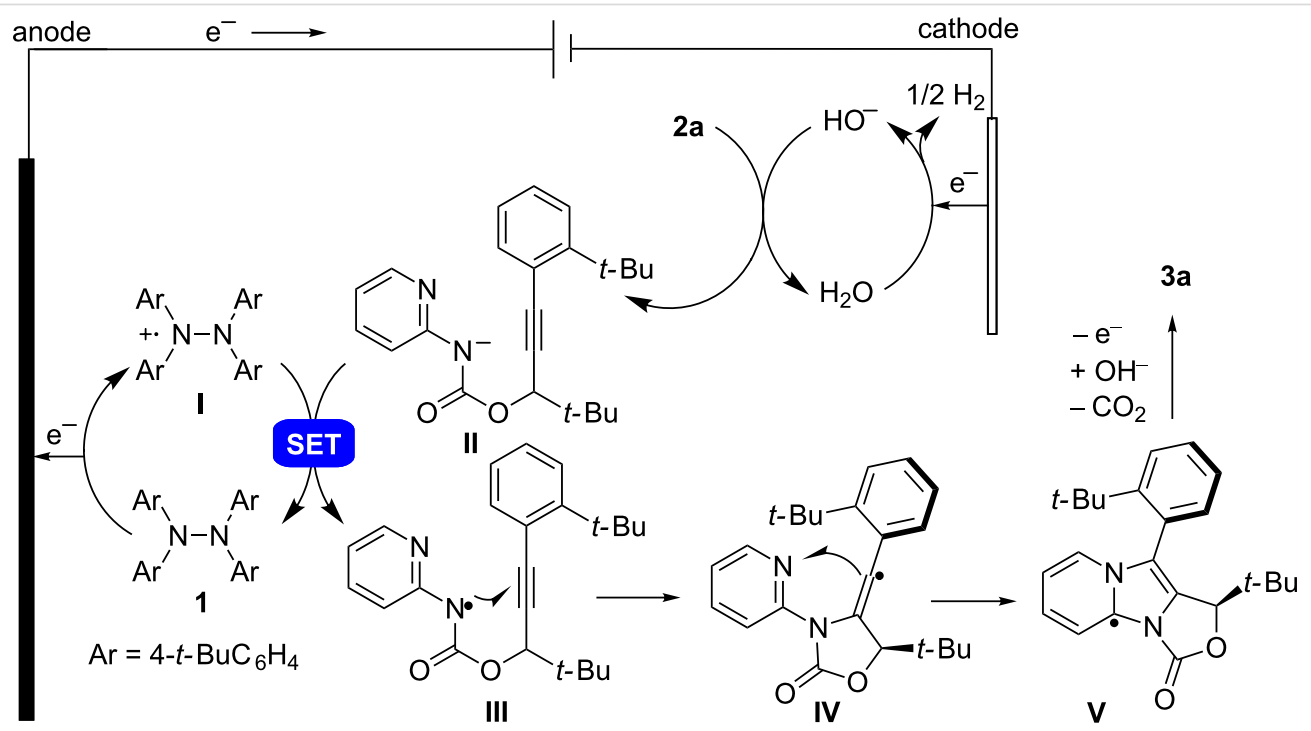

Scheme 3: Proposed reaction mechanism for the electrochemical synthesis of 3 a.

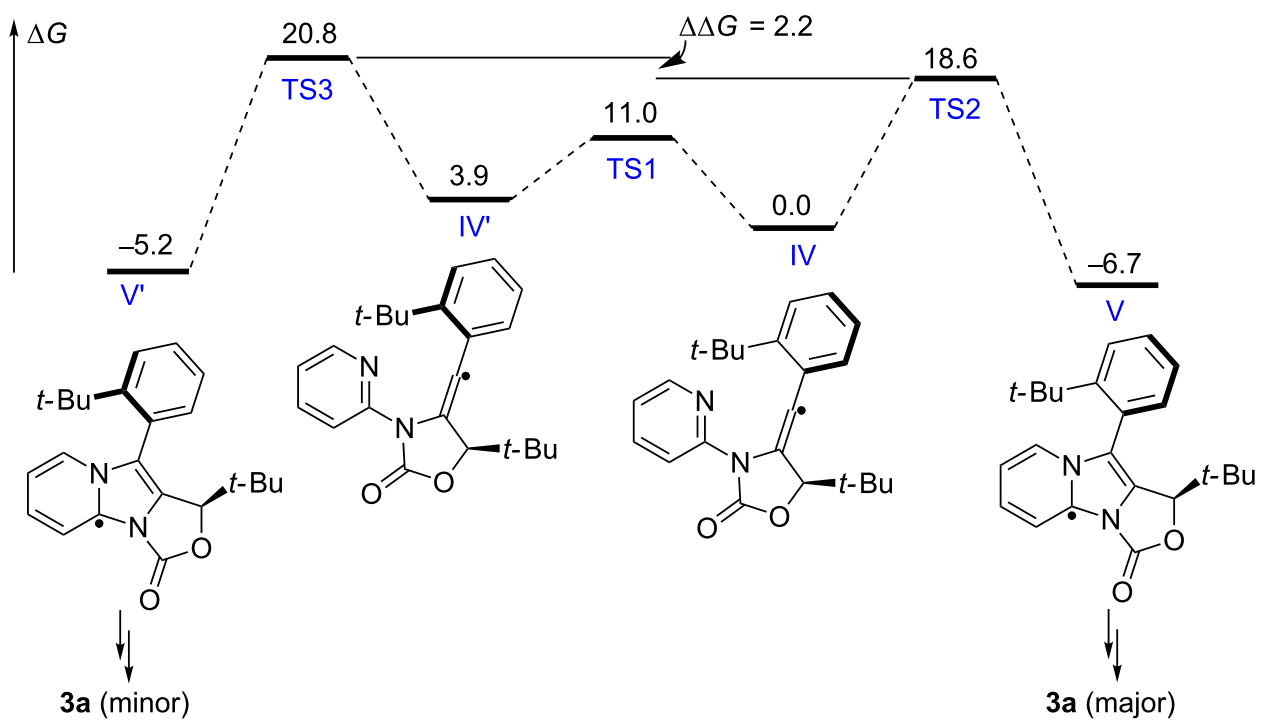

Scheme 4: Computation investigation on the vinyl radical cyclization. DFT (M06-2X/6-31G*) calculated energetics $\left(\mathrm{kcal}^{*} \mathrm{~mol}^{-1}\right)$ are $\mathrm{Gibbs}$ free energies in $\mathrm{MeCN}$. 
much faster than their respectively cyclizations to give $\mathbf{V}$ and $\mathbf{V}^{\prime}$. Since TS2 is relatively lower in energy than TS3, $\mathbf{V}$ is formed as the major product.

\section{Conclusion}

In summary, we have developed a diastereoselective approach for the synthesis of axially chiral biaryls through an electricitypowered cyclization cascade. The reactions employ easily assembled starting materials and afford functionalized imidazopyridine-based biaryls in good to high yields and diastereoselectivity.

\section{Supporting Information}

\section{Supporting Information File 1}

Experimental part.

[https://www.beilstein-journals.org/bjoc/content/

supplementary/1860-5397-15-76-S1.pdf]

\section{Acknowledgements}

Financial support of this research from MOST (2016YFA0204100), NSFC (21672178), and the Fundamental Research Funds for the Central Universities, is acknowledged.

\section{ORCID ${ }^{\circledR}$ iDs}

Jinshuai Song - https://orcid.org/0000-0002-1909-9253

Hai-Chao Xu - https://orcid.org/0000-0002-3008-5143

\section{References}

1. Bringmann, G.; Gulder, T.; Gulder, T. A. M.; Breuning, M. Chem. Rev. 2011, 111, 563-639. doi:10.1021/cr100155e

2. Pu, L. Chem. Rev. 1998, 98, 2405-2494. doi:10.1021/cr970463w

3. Tanaka, K. Chem. - Asian J. 2009, 4, 508-518. doi:10.1002/asia.200800378

4. Wallace, T. W. Org. Biomol. Chem. 2006, 4, 3197-3210. doi:10.1039/b608470m

5. Bringmann, G.; Price Mortimer, A. J.; Keller, P. A.; Gresser, M. J.; Garner, J.; Breuning, M. Angew. Chem., Int. Ed. 2005, 44, 5384-5427. doi:10.1002/anie.200462661

6. Ma, G.; Sibi, M. P. Chem. - Eur. J. 2015, 21, 11644-11657. doi:10.1002/chem.201500869

7. Link, A.; Sparr, C. Chem. Soc. Rev. 2018, 47, 3804-3815. doi:10.1039/c7cs00875a

8. Wang, Y.-B.; Tan, B. Acc. Chem. Res. 2018, 51, 534-547. doi:10.1021/acs.accounts.7b00602

9. Yang, H.; Yang, X.; Tang, W. Tetrahedron 2016, 72, 6143-6174. doi:10.1016/j.tet.2016.08.042

10. Wencel-Delord, J.; Panossian, A.; Leroux, F. R.; Colobert, F. Chem. Soc. Rev. 2015, 44, 3418-3430. doi:10.1039/c5cs00012b

11. Raut, V. S.; Jean, M.; Vanthuyne, N.; Roussel, C.; Constantieux, T.; Bressy, C.; Bugaut, X.; Bonne, D.; Rodriguez, J. J. Am. Chem. Soc. 2017, 139, 2140-2143. doi:10.1021/jacs.6b11079
12. Vorogushin, A. V.; Wulff, W. D.; Hansen, H.-J. J. Am. Chem. Soc. 2002, 124, 6512-6513. doi:10.1021/ja0201505

13. Guo, F.; Konkol, L. C.; Thomson, R. J. J. Am. Chem. Soc. 2011, 133, 18-20. doi:10.1021/ja108717r

14. Qiu, L.; Kwong, F. Y.; Wu, J.; Lam, W. H.; Chan, S.; Yu, W.-Y.; Li, Y.-M.; Guo, R.; Zhou, Z.; Chan, A. S. C. J. Am. Chem. Soc. 2006, 128, 5955-5965. doi:10.1021/ja0602694

15. Kärkäs, M. D. Chem. Soc. Rev. 2018, 47, 5786-5865. doi:10.1039/c7cs00619e

16. Zhao, Y.; Xia, W. Chem. Soc. Rev. 2018, 47, 2591-2608. doi:10.1039/c7cs00572e

17. Chen, J.-R.; Hu, X.-Q.; Lu, L.-Q.; Xiao, W.-J. Chem. Soc. Rev. 2016, 45, 2044-2056. doi:10.1039/c5cs00655d

18. Zard, S. Z. Chem. Soc. Rev. 2008, 37, 1603-1618. doi:10.1039/b613443m

19. Xiong, T.; Zhang, Q. Chem. Soc. Rev. 2016, 45, 3069-3087. doi:10.1039/c5cs00852b

20. Yan, M.; Kawamata, Y.; Baran, P. S. Chem. Rev. 2017, 117, 13230-13319. doi:10.1021/acs.chemrev.7b00397

21. Wiebe, A.; Gieshoff, T.; Möhle, S.; Rodrigo, E.; Zirbes, M.; Waldvogel, S. R. Angew. Chem., Int. Ed. 2018, 57, 5594-5619. doi:10.1002/anie.201711060

22. Möhle, S.; Zirbes, M.; Rodrigo, E.; Gieshoff, T.; Wiebe, A.; Waldvogel, S. R. Angew. Chem., Int. Ed. 2018, 57, 6018-6041. doi:10.1002/anie.201712732

23. Feng, R.; Smith, J. A.; Moeller, K. D. Acc. Chem. Res. 2017, 50, 2346-2352. doi:10.1021/acs.accounts.7b00287

24. Moeller, K. D. Chem. Rev. 2018, 118, 4817-4833. doi:10.1021/acs.chemrev.7b00656

25. Yan, M.; Kawamata, Y.; Baran, P. S. Angew. Chem., Int. Ed. 2018, 57, 4149-4155. doi:10.1002/anie.201707584

26. Yang, Q.-L.; Fang, P.; Mei, T.-S. Chin. J. Chem. 2018, 36, 338-352. doi:10.1002/cjoc.201700740

27. Tang, S.; Liu, Y.; Lei, A. Chem 2018, 4, $27-45$. doi:10.1016/j.chempr.2017.10.001

28. Yoshida, J.-i.; Kataoka, K.; Horcajada, R.; Nagaki, A. Chem. Rev. 2008, 108, 2265-2299. doi:10.1021/cr0680843

29. Jiang, Y.; Xu, K.; Zeng, C. Chem. Rev. 2018, 118, 4485-4540. doi:10.1021/acs.chemrev.7b00271

30. Francke, R.; Little, R. D. Chem. Soc. Rev. 2014, 43, 2492-2521. doi:10.1039/c3cs60464k

31. Hou, Z.-W.; Mao, Z.-Y.; Melcamu, Y. Y.; Lu, X.; Xu, H.-C. Angew. Chem., Int. Ed. 2018, 57, 1636-1639. doi:10.1002/anie.201711876

32. Hou, Z.-W.; Yan, H.; Song, J.-S.; Xu, H.-C. Chin. J. Chem. 2018, 36, 909-915. doi:10.1002/cjoc.201800301

33. Hou, Z.-W.; Mao, Z.-Y.; Song, J.; Xu, H.-C. ACS Catal. 2017, 7, 5810-5813. doi:10.1021/acscatal.7b02105

34. Hou, Z.-W.; Mao, Z.-Y.; Zhao, H.-B.; Melcamu, Y. Y.; Lu, X.; Song, J.; Xu, H.-C. Angew. Chem., Int. Ed. 2016, 55, 9168-9172. doi:10.1002/anie.201602616

35. Gieshoff, T.; Kehl, A.; Schollmeyer, D.; Moeller, K. D.; Waldvogel, S. R. J. Am. Chem. Soc. 2017, 139, 12317-12324. doi:10.1021/jacs.7b07488

36. Xu, H.-C.; Moeller, K. D. J. Am. Chem. Soc. 2008, 130, 13542-13543. doi:10.1021/ja806259z

37. Gieshoff, T.; Schollmeyer, D.; Waldvogel, S. R. Angew. Chem., Int. Ed. 2016, 55, 9437-9440. doi:10.1002/anie.201603899

38. Kehl, A.; Breising, V. M.; Schollmeyer, D.; Waldvogel, S. R. Chem. - Eur. J. 2018, 24, 17230-17233. doi:10.1002/chem.201804638 
39. Lin, M.-Y.; Xu, K.; Jiang, Y.-Y.; Liu, Y.-G.; Sun, B.-G.; Zeng, C.-C. Adv. Synth. Catal. 2018, 360, 1665-1672.

doi:10.1002/adsc.201701536

40. Zhang, S.; Li, L.; Xue, M.; Zhang, R.; Xu, K.; Zeng, C. Org. Lett. 2018, 20, 3443-3446. doi:10.1021/acs.orglett.8b00981

41. Hu, X.; Zhang, G.; Bu, F.; Nie, L.; Lei, A. ACS Catal. 2018, 8, 9370-9375. doi:10.1021/acscatal.8b02847

42. Seeman, J. I. J. Chem. Educ. 1986, 63, 42-48. doi:10.1021/ed063p42

\section{License and Terms}

This is an Open Access article under the terms of the Creative Commons Attribution License

(http://creativecommons.org/licenses/by/4.0). Please note that the reuse, redistribution and reproduction in particular requires that the authors and source are credited.

The license is subject to the Beilstein Journal of Organic Chemistry terms and conditions:

(https://www.beilstein-journals.org/bjoc)

The definitive version of this article is the electronic one which can be found at: doi:10.3762/bjoc. 15.76 